\title{
Effect of red mud addition on the corrosion parameters of reinforced concrete evaluated by electrochemical methods
}

\section{Efeito da adição da lama vermelha na corrosibilidade do concreto armado avaliado por meio de técnicas eletroquímicas}
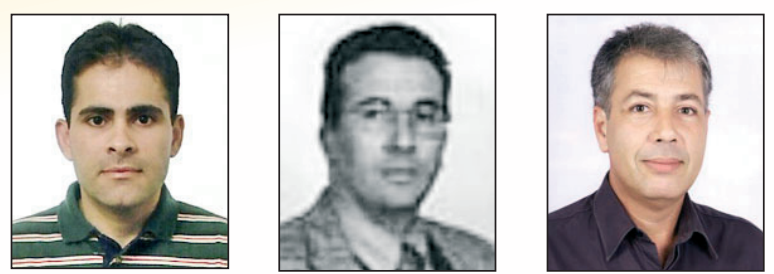

D.V. RIBEIRO a verasribeiro@hotmail.com

J.A. LABRINCHA ${ }^{b}$

jal@ua.pt

M.R. MORELLI ${ }^{\circ}$ morelli@power.ufscar.br

\begin{abstract}
Red mud, the main waste generated in aluminum and alumina production from bauxite ore by the Bayer process, is considered "hazardous" due to its high $\mathrm{pH}$. The high $\mathrm{pH}$ also provides greater protection of rebars, which is reflected in the low corrosion potential and high electrical resistivity (filler effect) of concrete. The corrosion potential was monitored by electrochemical measurements and the electrical resistivity was evaluated using sensors embedded in concrete test specimens. The results showed that the addition of red mud is beneficial to concrete, reducing its corrosion potential and increasing its electrical resistivity. Red mud proved to be a promising additive for concrete to inhibit the corrosion process.
\end{abstract}

Keywords: concrete, red mud, concrete, corrosion potential, electrical resistivity.

\section{Resumo}

A lama vermelha é um resíduo sólido gerado no processo de beneficiamento da bauxita e, devido a seu elevado pH, é considerado "perigoso". $\mathrm{O}$ elevado pH da lama vermelha proporciona uma maior proteção à armadura do concreto, o que é refletido no baixo potencial de corrosão da armadura e elevada resistividade elétrica (efeito filler) do concreto. O potencial de corrosão foi monitorado por medidas eletroquímicas e a resistividade elétrica foi avaliada com o uso de sensores embutidos nas amostras de concreto. Os resultados obtidos mostraram que a adição da lama vermelha é benéfica ao concreto, reduzindo o potencial de corrosão e aumentando a resistividade elétrica. Assim, a lama vermelha apresenta-se como uma promissora adição ao concreto armado, no intuito de inibir o processo corrosivo.

Palavras-chave: concreto, lama vermelha, concreto, potencial de corrosão, resistividade elétrica.

a Federal University of Bahia, Department of Materials Science and Technology, verasribeiro@hotmail.com, Escola Politécnica - Rua Aristides Novis, 02, Federação, 40210-630. Salvador/BA, Brazil;

b University of Aveiro \& CICECO, Ceramics and Glass Engineering Dept., jal@ua.pt, Campus Universitário de Santiago, 3810-193. Aveiro, Portugal;

Federal University of São Carlos, Department of Materials Engineering, morelli@power.br, Rodovia Washington Luis, Km 235. 13566-550.

São Carlos/SP, Brazil. 


\section{Introduction}

The world's production of bauxite in 2009 was 205 million tons, and the main producing countries were Australia, China, Brazil, Guinea, India and Jamaica. Ranking third in worldwide production in 2009, Brazil produced 26.6 million tons of bauxite. It also has the world's third largest bauxite ore reserves (around 3.5 billion tons), concentrated mainly in the northern part of the country (state of Pará) [1]. Roughly $0.3-1.0$ tons of red mud waste are generated per ton of aluminum produced. Brazil has discarded about 10.6 million tons/year of caustic red mud in recent years and the worldwide generation of red mud exceeds 117 million tons/year [2] The storage of large quantities of alkaline residue (red mud) is expensive (between 1 and $2 \%$ of the price of alumina), requiring large disposal areas (about 1 square kilometer for five years of production for a factory producing 1 million tons of alumina per year) and causing serious environmental problems [3]. Therefore, the use of this waste in cement matrices is very attractive since the high amount of cement consumed worldwide is compatible with the high generation of this waste.

Alkaline matrices such as those provided by Portland cement in mortars and concrete are commonly used in waste conditioning. They are inexpensive, have an extensively documented history of safe use, and are a draw-upon readily-accessible technology. Alkalinity greatly reduces the solubility of many hazardous inorganic species and inhibits microbiological processes. Moreover, since these matrices require water for hydration, they may readily incorporate wet wastes [1] such as red mud. Red mud was chosen for this study due to its high alumina and iron oxides contents.

The search for an economically and environmentally viable alterna- tive has led to the study of red mud for various applications, such as adsorbent for the removal of heavy metals from aqueous solutions [4], building materials such as bricks [5], ceramics and tiles [6], ceramic glazes [7], as polymer-based composites to replace wood [8], iron-rich cement $[9,10]$, component of clinker $[3,9,10]$, and the addition to mortar and concrete formulations was also reported [11]. The use as common building material has been suggested as an alternative that ensures high rates of consumption [12].

The high alkalinity of red mud, which was initially a factor of environmental concern, now emerges as a major asset in the attempt to use red mud as an inhibitor of reinforced concrete rebar corrosion by retaining its passivity. To evaluate this possibility, rebar corrodibility was examined by corrosion potential and electrical resistivity measurements.

By analyzing the results compared with reference samples (without waste addition), intended to determine the viability of the red mud as an addition to Portland cement matrices providing an appropriate and less costly destination.

Thus, we sought an alternative for two actually problems: corrosion in reinforced concrete, which consumes millions of dollars with the maintenance and revitalization of infrastructure, and the environmental damage caused by industrial solid waste disposal, one of the biggest questions to be solved in this century.

\section{Materials and Methods}

\subsection{Materials}

Ordinary CP-II 32 Z Portland cement (OPC), according to the Brazil-

Figure 1 - (A) and (B) Scheme of the exposed rebar area (in $\mathrm{mm}$ ); (C) sample dimensions (in $\mathrm{mm}$ ); and (D) steel rebar positions in concrete samples
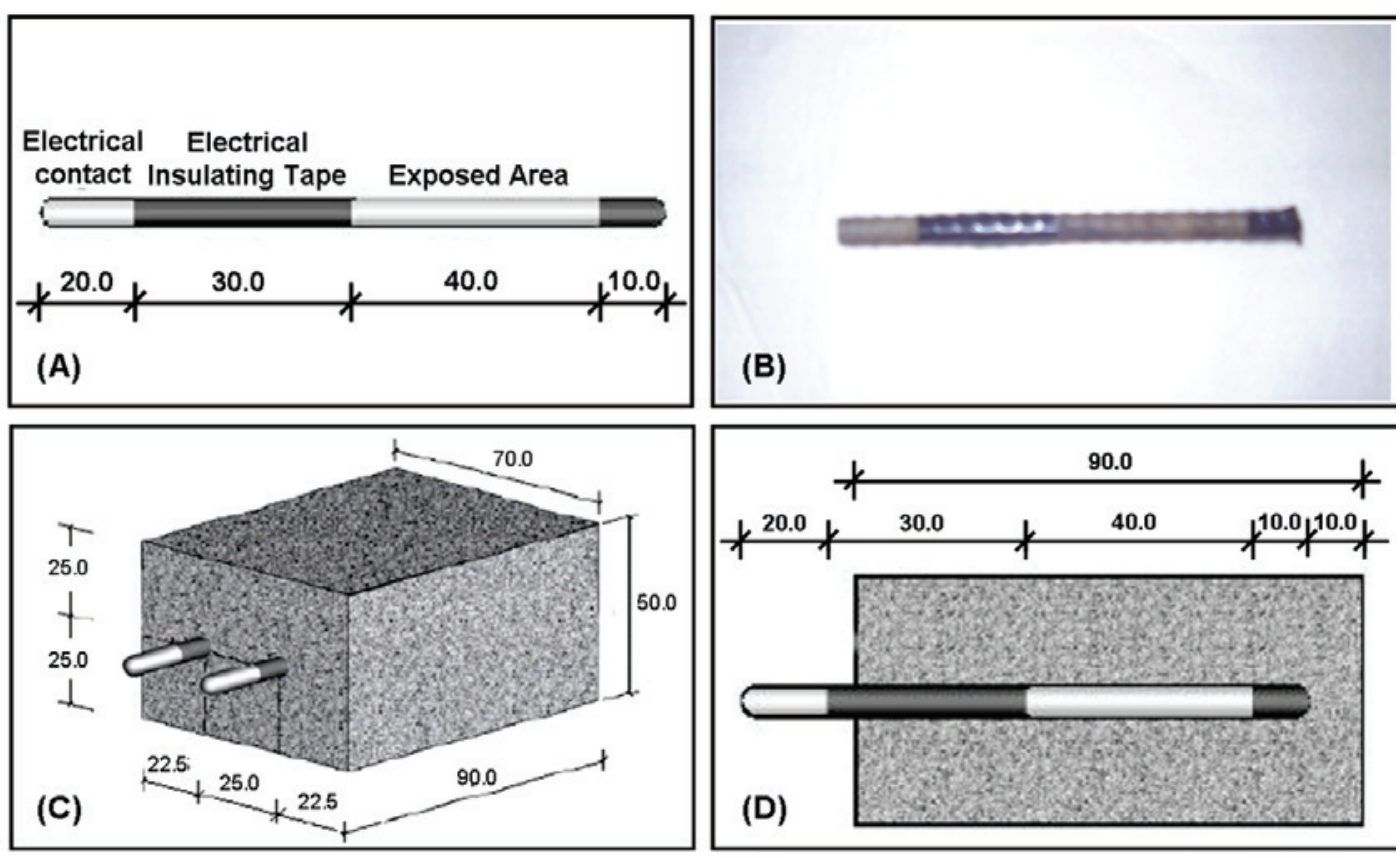
ian NBR 11578 standard, commercially available in São Carlos, Brazil, was selected as reference in all the tests. The coarse aggregate was dense, crushed granitic stone and the sand was supplied from a river deposit commercially available in São Carlos, Brazil.

The red mud came from Poços de Caldas-MG and was supplied by ALCOA Brazil. It is a mixture containing about $60 \%$ of solids, collected immediately after alumina recovery from the digestion process.

\subsection{Methods}

\subsubsection{Materials characterization and Concrete Dosage}

The materials characterization involved X-ray diffraction (Rigaku Geirgeflex ME 210GF2 Diffractometer) and X-ray fluorescence (Philips PW1480 X-ray Fluorescence Spectrometer) analyses, while physical parameters such as the specific surface area (estimated by BET, using a Micrometrics Gemini 2370 V1.02 equipment) and specific gravity (Helium Pycnometer Accupyc 1330 V2.01 from Micrometrics) were also determined. Similar determinations were performed on sand and on the red mud.

The concrete formulation used as reference was prepared in a 1.0 : $1.5: 1.3: 0.5$ (Portland cement + red mud : sand : coarse aggregate : water) weight ratio. The mortar content was $65.8 \%$ and the cement consumption was $540 \mathrm{~kg} / \mathrm{m}^{3}$ compared to a reference mixture. Distinct concrete mixtures in which cement was partially replaced by red mud $(10,20$, and $30 \%$ in weight) were analyzed.

To corrosion potential measurements, two commercial steel rebars (Gerdau, type CA-50) with a diameter of $6.3 \mathrm{~mm}$ were embedded in each prismatic concrete block $\left(50 \times 70 \times 90 \mathrm{~mm}^{3}\right)$ with a concrete topping of $2.25 \mathrm{~cm}$. With this geometry, the distance between the inner surfaces of the steel rebars was $2.5 \mathrm{~cm}$ and the exposed embedded area of each electrode was $15.83 \mathrm{~cm} 2$. The electrical resistivity of the concrete was tested using molded concrete blocks $\left(200 \times 200 \times 100 \mathrm{~mm}^{3}\right)$ with sensors embedded in them. All the specimens were unmolded $24 \mathrm{~h}$ after being cast and were cured for 28 days in a humid chamber (>95\% HR). A minimum of 4 samples were tested in all determinations.

\subsubsection{Corrosion Potential}

The reinforcement steel bars were weighed on an analytical balance with an accuracy of $0.01 \mathrm{~g}$. The area exposed to chloride attack (about $15.83 \mathrm{~cm}^{2}$ ) was then delimited by electrical insulating tape, as shown in Figure 1. The bars were positioned so that the exposed area was located in the central region of the specimens, as illustrated in Figure 1d.

The corrosion potential is basically verified from a chloride-activated accelerated corrosion test. The electrochemical cell used for corrosion potential measurements was composed of a working electrode, the reinforcement steel bars and the saturated calomel electrode (SCE) used as reference electrode.

Before taking the measurements, the side of the specimens to be measured was pre-moistened with a wet sponge for one minute. A conductive solution containing $5 \mathrm{~mL}$ of neutral detergent to one liter of water, according to the ASTM C-876/91 standard (Standard Test Method for Half-Cell Potentials of Uncoated Reinforcing Steel in Concrete) and an electrical conductivity of $0.15 \pm 0.02 \mathrm{mS} / \mathrm{cm}$ were used. For the measurements, the reference electrode was positioned approximately at mid-span over the rebar under analy- sis. The contact between the reference electrode and the specimen was aided with a damp sponge.

The corrosion test was started after 63 days, when the specimens showed a constant mass (1.0 gram of variation in two consecutive 24-hour readings) and when the measured corrosion potential indicated the formation of a passive film on the surface of the steel bars (Ecor $>-0.124 \mathrm{~V}$ ). This reference value corresponds to a lower than $10 \%$ possibility of corrosion occurrence, according to the ASTM C 876/91 standard (for the saturated calomel electrode used in this work).

In other works [13, 14], it was necessary to define a specific age, or reference age, from which the procedures of the accelerated corrosion tests started. The authors of those studies associated the reference age to the stabilization of the cement hydration process and defined the ages of 63 days [14] and 80 days [13] as sufficient for the cement paste to acquire a relatively well developed physical structure and a significantly high degree of hydration.

After reaching the "safe potential," the specimens were subjected to semi-cycles of partial immersion in $3 \mathrm{wt} \% \mathrm{NaCl}$ solution for two days and semi-cycles of drying in a ventilated oven at $50{ }^{\circ} \mathrm{C}$ for five days. During the semi-cycle of partial immersion, the level of immersion solution was kept at half height of the specimens. In this condition, the chloride inflow occurs primarily by capillary absorption, since the specimens are first dried, and after the pores become saturated, the inflow occurs by diffusion, which is accelerated due to water evaporation through the exposed concrete. The corrosion potential (Ecorr) was measured at the end of each semi-cycle.

According to MCCARTER apud SANTOS [13], in a porous material, there is a relationship between the force of capillary suction and the saturation degree. Thus, when there is a region exposed and dried, the suction forces will be greater and will result in a faster water movement within the concrete.

The concentration of $3 \mathrm{wt} \% \mathrm{NaCl}$ was taken to be a concentration close to that presented by seawater, in addition to be the critical concentration do rebar corrosion. The concentration of the dipping solution was measured before each half-cycle of wetting and adjusted when necessary. Furthermore, this solution used was replaced by a new solution with the same concentration after four cycles.

At the end of each half-cycle were measured the corrosion potential $\left(E_{\text {cor }}\right)$ and the mass of the specimens. The corrosion potential was used as an indicative of the bars passivation.

The active state of corrosion (Ecorr $<-0.274 \mathrm{~V}$ ) or passive state (Ecorr > $-0.124 \mathrm{~V}$ ) was analyzed based on the corrosion potential (Ecorr), using the saturated calomel electrode (SCE) as reference. The test was concluded when two consecutive and full cycles resulted in corrosion potential values below the critical value (Ecorr $<-0.274 \mathrm{~V}$ ).

After concluding the test, the rebars were extracted from the samples, cleaned according to the ASTM G-1/03 standard, and weighed to determine weight loss and to compare them with the initial value. Thus, the corrosion rate $(\mathrm{CR})$ can be calculated according to equation (1).

$$
T C=\frac{K \cdot W}{A \cdot T \cdot D}
$$


Figure 2 - (A) Schematic diagram of the measurement of concrete electrical resistance, (B) electrical probe used, and (C) electrical current measure

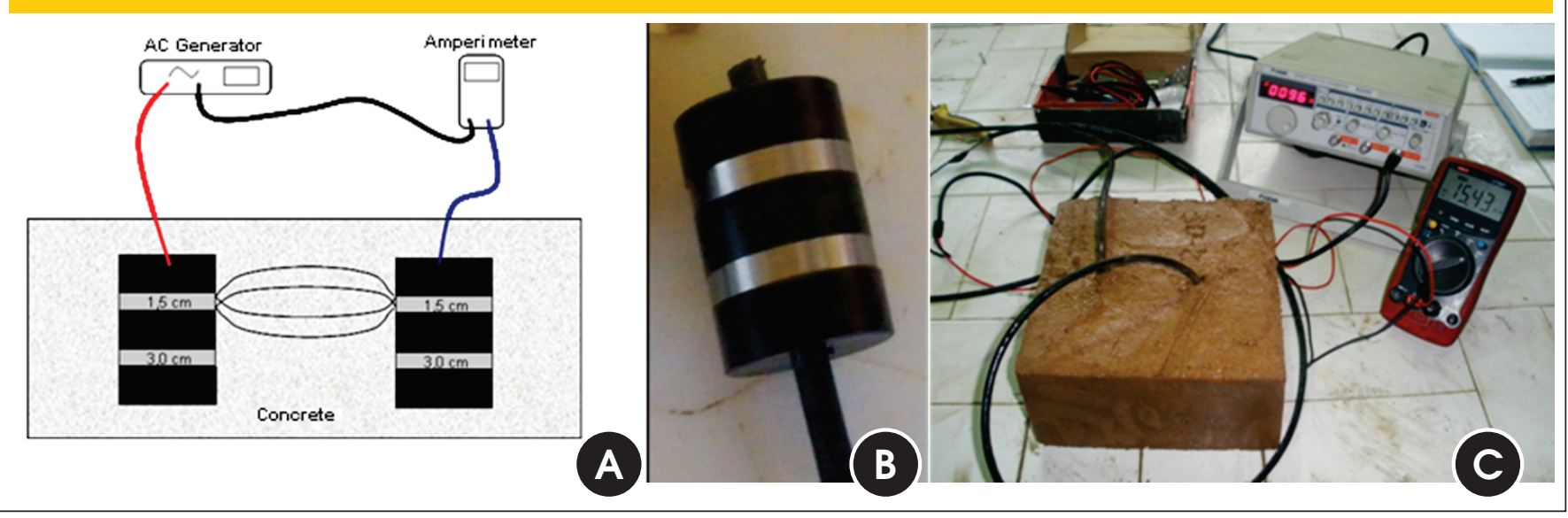

where $\mathrm{K}=$ constant (for $\mathrm{CR}\left(\mathrm{mm} /\right.$ year), $\mathrm{K}=8.76 \times 10^{7}$; for $\mathrm{CR}(\mathrm{g} /$ $\mathrm{m}^{2}$.year), $\left.\mathrm{K}=8.76 \times 10^{7} . \mathrm{D}\right) ; \mathrm{W}=$ weight loss (grams); $\mathrm{A}=$ exposed rebar area $\left(\mathrm{cm}^{2}\right) ; \mathrm{T}=$ exposure time (hours); $\mathrm{D}=$ steel rebar density (for CA-50 steel, $D=7.85 \mathrm{~g} / \mathrm{cm}^{3}$ ). In this study, $A=15.83 \mathrm{~cm}^{2}$ and $\mathrm{T}=4320$ hours (180 days).

\subsubsection{Electrical Resistivity}

The electrical resistivity of concrete was calculated from the electrical current (I) passing through the specimens. The system, which is shown schematically in Figure 2, consists of two cylindrical probes, each with two electrodes (different measurement levels) made of stainless steel (rings/washers) and spaced at different layer depths. The probes used in this study were supplied by the Institute of Corrosion (ICorr, Portugal), which specializes in corrosion studies. The two probes of the system should be placed $10 \mathrm{~cm}$ apart.

Through this monitoring system, the ionic resistivity of concrete at each depth can be determined by the paired-electrode technique. An alternating current is applied between the electrodes and the resistivity is determined by measuring the resistance (DE/DI, Ohm's law) and by a parameter that depends on the geometry of the electrodes and on the distance between them (A/L). Thus, the resistivity $(r)$ is calculated according to equation (2):

$$
\rho=\frac{V \cdot A}{I \cdot L}
$$

For circular electrodes, equation (2) is equivalent to:

$$
\rho=\frac{2 \pi \cdot V \cdot L}{I}
$$

where $\rho$ is the electrical resistivity of concrete $(\Omega . \mathrm{cm})$; $V$ is the applied voltage; $I$ is the current intensity; $A$ is the area of the side of the specimen in contact with the electrode $\left(\mathrm{cm}^{2}\right)$; and $\mathrm{L}$ is the distance between the electrodes $(\mathrm{cm})$. The European CE Bulletin - COST 509 (Corrosion and Protection of Metals in Contact with Concrete) was used as the evaluation parameter since it is more stringent in relation to values than those suggested by the CEB192 standard (Table 1).

\section{Results and discussion}

\subsection{Materials Characterization}

The Portland cement used here had a specific surface area of 0.93 $\mathrm{m}^{2} / \mathrm{g}$ and a specific gravity of $3.11 \mathrm{Kg} / \mathrm{dm}^{3}$. The sand had a specific surface area of $0.68 \mathrm{~m}^{2} / \mathrm{g}$ and a specific gravity of $2.70 \mathrm{Kg} / \mathrm{dm}^{3}$, classified by the Brazilian NBR 7211 standard as fine sand. The gravel had a specific gravity of $2.74 \mathrm{~kg} / \mathrm{dm}^{3}$ and a maximum dimension of $19 \mathrm{~mm}$.

The red mud was received in the form of paste containing about $40 \%$ free water. In the present study, the material was dried and crushed, and then used as a powdered additive. Ideally, to demonstrate its potential as a concrete constituent, red mud should be tested in the as-received condition; hence, the free water present in the mud should be considered a concrete mix component.

The red mud had a specific surface area of $20.27 \mathrm{~m}^{2} / \mathrm{g}$, its specific gravity was $2.90 \mathrm{~kg} / \mathrm{dm}^{3}$ and its $\mathrm{pH}$ was very high (12.95), exceeding the limit (12.5) established by the Brazilian NBR 10004 standard for non-hazardous wastes.

Table 2 presents the chemical composition of the waste, while Figure 3 shows the corresponding XRD pattern. As expected, the predominant crystalline components were aluminium hydroxide $\left(\mathrm{Al}(\mathrm{OH})_{3}\right)$, calcium carbonate $\left(\mathrm{CaCO}_{3}\right)$, and iron oxide $\left(\mathrm{Fe}_{2} \mathrm{O}_{3}\right)$, but relative amounts of $\mathrm{SiO}_{2}$, muscovite and $\mathrm{FeO}(\mathrm{OH})$ were also relevant. Some of those oxides were also detected by XRD, in addition to aluminium hydroxide and a complex $\mathrm{Na}_{5} \mathrm{Al}_{3} \mathrm{CSi}_{3} \mathrm{O}_{15}$ phase.

\subsection{Corrosion Potential}

Based on the corrosion potential measurements an analysis was 


\section{Table 1 - Probability of rebar corrosion activity as a function of ranges of corrosion potential of various reference electrodes in accordance with the ASTM C-876/91 standard}

\begin{tabular}{|c|c|c|c|}
\hline \multirow{2}{*}{ Electrode } & \multicolumn{3}{|c|}{ Probability of Rebar Corrosion Activity } \\
\hline & $<10 \%$ & $10 \%-90 \%$ & $>90 \%$ \\
\hline $\mathrm{NHE}^{\mathrm{a}}$ & $>0.118 \mathrm{~V}$ & $(0.118 V)-(-0.032 V)$ & $<-0.032 \mathrm{~V}$ \\
\hline $\begin{array}{c}\mathrm{Cu} / \mathrm{CuSO}_{4}, \mathrm{Cu}_{2}+ \\
(\mathrm{ASTM} \mathrm{C} \mathrm{876)}\end{array}$ & $>-0.200 \vee$ & $(-0.200 \mathrm{~V})-(-0.350 \mathrm{~V})$ & $<-0.350 V$ \\
\hline $\begin{array}{c}\mathrm{Hg}, \mathrm{Hg}_{2} \mathrm{Cl}_{2} / \mathrm{KCl} \\
\text { (saturated solution) }\end{array}$ & $>-0.124 \mathrm{~V}$ & $(-0.124 V)-(-0.274 V)$ & $<-0.274 V$ \\
\hline $\mathrm{Ag}, \mathrm{AgCl} / \mathrm{KCl}(1 \mathrm{M})$ & $>-0.104 \mathrm{~V}$ & $(-0.104 \mathrm{~V})-(-0.254 \mathrm{~V})$ & $<-0.254 \mathrm{~V}$ \\
\hline
\end{tabular}

Table 2 - Chemical composition of red mud estimated by XRF

\begin{tabular}{lcccccccccc} 
Component & $\mathrm{Al}_{2} \mathrm{O}_{3}$ & $\mathrm{Fe}_{2} \mathrm{O}_{3}$ & $\mathrm{Na}_{2} \mathrm{O}$ & $\mathrm{CaO}$ & $\mathrm{SiO}_{2}$ & $\mathrm{~K}_{2} \mathrm{O}$ & $\mathrm{MnO}$ & $\mathrm{THO}_{2}$ & Others & LOI $^{\circ}$ \\
Content (wt.\%) & 19.87 & 19.85 & 7.35 & 4.61 & 14.34 & 1.87 & 0.21 & 2.66 & 1.01 & 27.20 \\
\hline${ }^{a} \mathrm{LOI}=$ loss of ignition & & & & & & & & & & \\
\hline
\end{tabular}

made of the onset of rebar corrosion, i.e., the moment when the potential was below $-274 \mathrm{mV}$ (the probability of corrosion exceeds $90 \%$ for the saturated calomel electrode). Results obtained by BAUER apud SANTOS [13] show that, in most cases, the evaluation of the corrosion onset period based on corrosion potential tests is consistent with assessments based on more accurate electrochemical parameters such as corrosion intensity $\left(\mathrm{i}_{\text {corr }}\right)$.

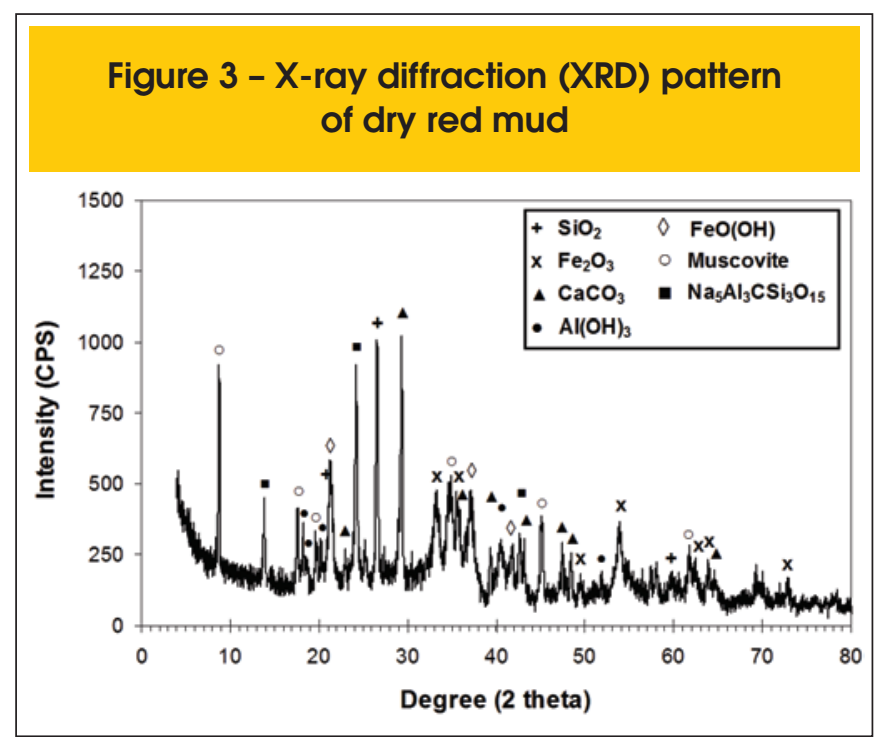

Figure 4 presents the results of the corrosion potential measurements. In the first 63 days, the specimens were not subjected to wetting and drying cycles in $\mathrm{NaCl}$ solution until the "safe potential" $(-124 \mathrm{mV})$ was reached, and the tests were interrupted when the "unsafe potential" $(-274 \mathrm{mV})$ was reached in two consecutive dry state measurements. The values represent the average of six measurements taken for each composition. The error bars were not placed in graphs because they would render the graphs very confusing and difficult to visualize. However, it can be stated that the results were highly reproducible, with a variation of less than $6 \%$.

One of the aspects of the test procedure adopted is that the rebar corrosion potential varied throughout the test, showing more negative or more positive values depending on the semi-cycle to which the specimen was subjected.

The most positive corrosion potential values were recorded after the drying cycles because, due to the decreasing amount of electrolyte, the concentration of dissolved substances increased. In fact, according to the Nernst equation, the equilibrium potential increases with the increase in activity, i.e., the increase in the effective concentrations of oxidized substances. Studies by SANTOS [13] confirm this behavior and show an inverse correlation between the corrosion potential and the concrete's moisture content, indicating that an increase in moisture content implies a decrease in the measured rebar corrosion potential.

According to the results shown in Figure 4, the reference samples showed a greater difference between the corrosion potential mea- 


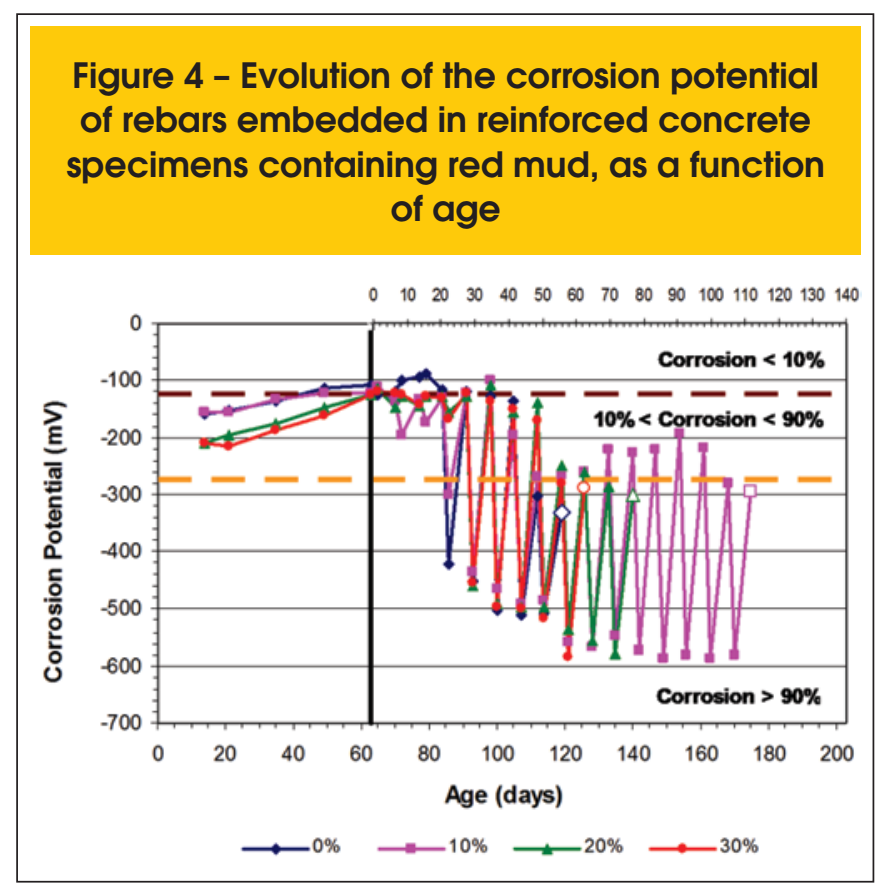

surements in the wet and dry states $(0 \%)$. Due a larger network of capillary pores, the reference samples presented a higher absorption capacity (capillary suction) and greater difficulty in losing this moisture (lower porosity) than the other samples.

The tests were interrupted when the "unsafe potential" was reached in samples in the dry state. For a better view, these results are presented in Figure 5. As can be seen, the reinforcing bars in specimens containing red mud took longer to depassivate than the reference samples, regardless of the amount of red mud added.

These results indicate only the onset of the corrosion process, without, however, presenting quantitative information about the phenomenon. Although they reached the end of test more quickly, the specimens that reached the unsafe potential continued to be subjected to wetting and drying cycles for up to 180 days, when the

\section{Figure 5 - Rebar corrosion onset period as a function of red mud content}

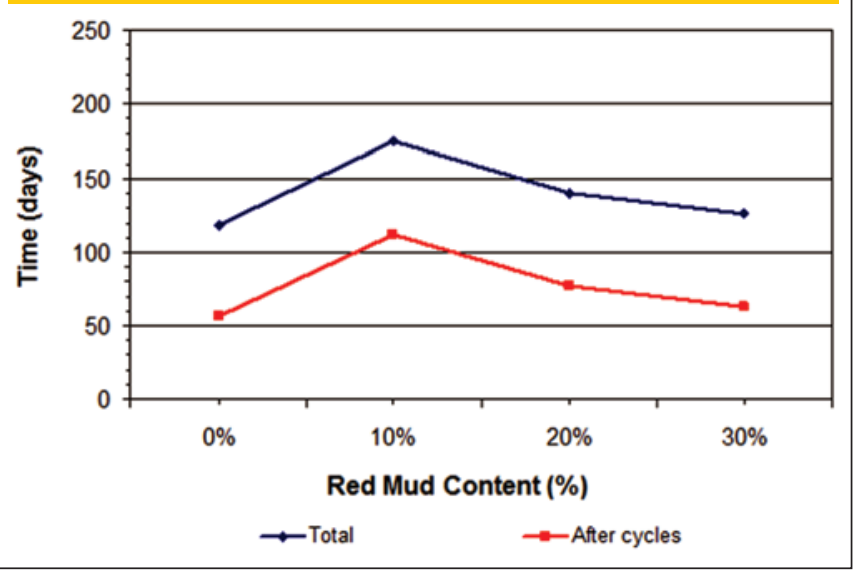

Figure 6 - Corrosion rate of steel bars embedded in reinforced concrete specimens, calculated after the corrosion potential test, as a function of red mud content

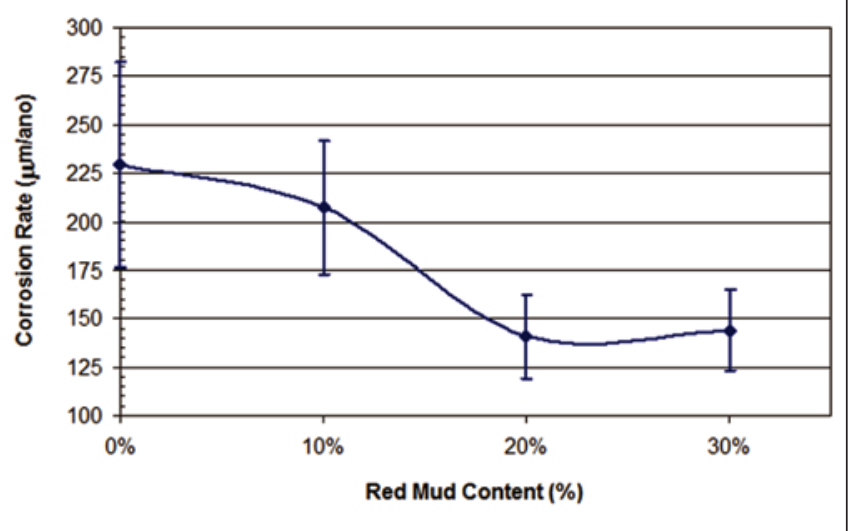

last samples (10\%) reached this potential. Thus, it was possible to calculate the corrosion rate of all the samples according to equation (A). The results are shown in Figure 6.

According to these results, the higher the content of red mud the lower the corrosion rate, which reached stability between $20 \mathrm{wt} \%$ and $30 \mathrm{wt} \%$ of red mud content. This behavior may be due to three isolated factors or to their combination: i) increasing alkalinity in the region near the steel-concrete interface; and/or ii) greater anchoring of chloride ions due to the presence of sodium aluminosilicates, which prevent the free movement of these ions and make them unavailable to start the corrosion process, as discussed with respect to the results of the chloride migration test; and/or iii) according to MCCARTER apud SANTOS [13], larger pores (existing in the specimens containing red mud) lose water more easily than the small and tortuous pores that are present in the reference sample.

\section{Figure 7 - Electrical resistivity of concrete specimens containing red mud, as a function of age}

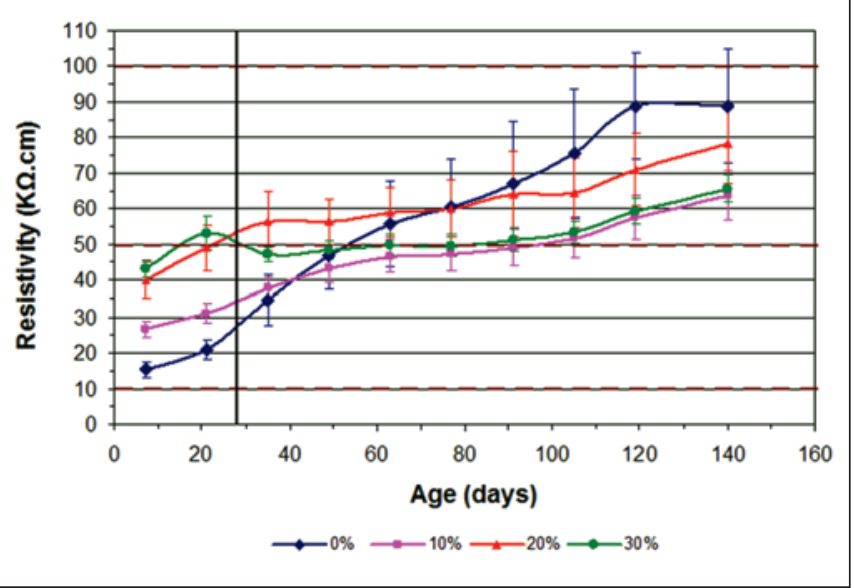


Therefore, no clear correlation was found between rebar depassivation time and corrosion rate, i.e., the rebar corrosion process may begin sooner, but after this moment, the corrosion process may occur at a lower rate. However, this may have occurred simply due to our reliance on the parameters defined in the ASTM 876 standard to determine the onset of corrosion and the variation in the half-cell potential measured by our technique with the location of the anodic areas on the rebar surface.

The specialized literature offers controversial explanations about phenomena involving corrosion potentials. However, it seems there is a consensus that this technique is insufficient and should always be accompanied by some other technique to quantitatively determine the corrosion kinetics of rebars $[15,16]$.

\subsection{Electrical Resistivity}

Electrical resistivity is a property widely used to monitor concrete structures because it is a nondestructive method and allows for external monitoring by means of embedded electrodes. This property is fundamentally related to fluid permeability and to ion diffusivity through concrete pores.

Several authors $[13,17,18,19,20]$ have shown that electrical resistivity is related to the microstructural characteristics of the cement matrix, such as porosity, pore size distribution, pore connectivity, and the conductivity of the aqueous solution in the matrix. In this study, three specimens were prepared for each amount of red mud content, providing a total of six results (each specimen yielded two different measures because of the two electrodes embedded at different measuring depths).

Figure 7 shows the average results of the electrical resistivity of the reference specimens $(0 \%)$ and the specimens containing red mud additions (10\%, $20 \%$ and $30 \%)$. The specimens were kept in a moist chamber up to the age of 28 days, and the dotted lines in the figure represent the corrosion risk levels: high $(<10 \mathrm{~K} \Omega . \mathrm{cm})$, moderate $(10-50 \mathrm{~K} \Omega . \mathrm{cm})$, low $(50-100 \mathrm{~K} \Omega . \mathrm{cm})$, and insignificant (> $100 \mathrm{~K} \Omega . \mathrm{cm}$ ), according to the COST 509.

All the samples showed increased electrical resistivity due to increased paste hydration and to the reduction of fluid concentration in concrete pores as the specimens became increasingly dry, making them less conductive. According to ANDRADE [21] and SANTOS [13], the conduction of electrical current through concrete occurs through continuous pores and microcracks that are present in the matrix and filled with water

The behavior of the specimens differed significantly according to different moisture contents. Among the specimens that were kept in the moist chamber (up to 28 days), the samples containing red mud were more resistive than the reference samples $(0 \%)$. This effect continued to be visible in the first days after the specimens' removal from the moist chamber.
After drying the specimens, the reference samples showed a high increase in resistivity which exceeded that of the 40 to 80 -day-old samples containing red mud. This effect can be explained by the high ionic concentration of red mud, which becomes more pronounced and active as the moisture content decreases when compared to reference samples. A similar behavior was observed by WHITING and NAGI [18]. The equivalent electrical conductivities of aqueous ions typically found in concrete pores were determined by ADAMSON apud SHI [16] and these values are presented in Table 3. As can be seen, the $\mathrm{Na}^{+}, \mathrm{OH}^{-}, \mathrm{Ca}^{2+}$ and $\mathrm{K}^{+}$ions in red mud are highly conductive, contributing to lower the resistivity of concrete when it loses moisture. Another factor to be considered is the higher porosity of concrete specimens containing red mud, which contributes decisively in reducing resistivity. Although they showed lower resistivity values than the reference samples, the samples of concrete containing red mud showed values well above the limit considered as low corrosion probability $>50$ $\mathrm{K} \Omega . \mathrm{cm}$ ). Hence, even if the presence of red mud does not prevent the occurrence of corrosion, it also cannot be considered harmful.

Another positive analysis factor is that the specimens containing red mud showed a higher resistivity in a humid environment, which is more conducive to corrosion. Unfortunately no measurements were taken of specimens kept moist throughout the experiment in order to verify if this behavior would be maintained.

\section{Conclusions}

This research led to the following conclusions:

- Electrical resistivity is a good indicator of the possible occurrence of chloride ion penetration. Thus, the higher the concrete's resistivity, the lower the penetration of chloride ions, and hence, the lower the probability of corrosion;

- The degree of saturation (humidity) of the concrete samples containing red mud appears to exert a considerable influence on the concrete's resistivity;

- The concrete specimens containing red mud presented higher resistivity in a humid environment, which is more favorable for corrosion.

- Evaluating the evolution of the corrosion process by corrosion potential tests is not possible; moreover, this technique only indicates the possibility of corrosion occurring, and should therefore be used as a complementary technique;

- The difference between the corrosion potential measures in wet and dry states is more pronounced in the reference samples $(0 \%)$ which, due to their larger network of capillary pores, have a higher capacity to absorb $\mathrm{NaCl}$ solutions (capillary suction) and greater difficulty in losing this moisture (lower porosity) than samples containing red mud.

- The depassivation process of reinforcing bars is retarded by the presence of red mud.

\section{Table 3 - Equivalent conductivity $\left(\lambda_{0}\right)$ of aqueous ions in infinite concentrations at $25{ }^{\circ} \mathrm{C}$ (ADAMSON apud SHI (16))}

\begin{tabular}{|c|c|c|c|c|c|c|}
\hline Ion & $\mathrm{Na}^{+}$ & $\mathrm{K}^{+}$ & $\mathrm{Ca}^{2+}$ & $\mathrm{SO}_{4}^{2-}$ & $\mathrm{OH}^{-}$ & $\mathrm{Cl}^{-}$ \\
\hline$\lambda_{0}\left(\mathrm{~m}^{-1} \boldsymbol{\Omega}^{-1}\right)$ & 0.00501 & 0.00735 & 0.00595 & 0.00798 & 0.0198 & 0.00763 \\
\hline
\end{tabular}




\section{Acknowledgements}

The authors wish to thank the FAPESB - Bahia Research Foundation, PPGCEM/UFSCar - The Postgraduate Program in Materials Science and Engineering at the Federal University of São Carlos (Brazil) and the UA/DECV - Ceramics and Glass Engineering Dept., University of Aveiro \& CICECO (Portugal) - Project FCTPTDC/CTM/65243/ 2006, for their support of this research. *This project did not have the financial support of Alcoa Brazil.

\section{References}

[01] IBRAM - Brazilian Mining Association. Bauxita. Disponível em: <www.ibram.org.br/sites/1300/1382/00000033.pdf>. Acesso em: 15 out. 2010.

[02] ROSKILL REPORTS. The Economics of Bauxite \& Alumina. Disponível em: $<w w w . r o s k i l l . c o . u k / i n d e x . h t m l>$. Acesso em: 20 nov. 2010.

[03] SINGH, M.; UPADHAYAY, S.N.; PRASAD, P.M. Preparation of special cements from red mud. Waste Management, v. 16, n. 8, p. 665-670, 1996.

[04] AMRITPHALE, S.S. et al. A novel process for making radiopaque materials using bauxite-Red mud. Journal of the European Ceramic Society. v. 27, n. 4, p. 1945-1951, 2007.

[05] AMRITPHALE, S.S.; PATEL, M. Utilisation of red mud, fly ash for manufacturing bricks with pyrophyllite. Silicates Ind, v. 2, n. 3, p. 31-35, 1987.

[06] VINCENZO, M.S.; RENZ, C.; STEFANO, M.; GIOVANNI, C. Bauxite red mud in the ceramic industry. Part 2: production of clay based ceramics. Journal of the European Ceramic, v. 20, n. 3, p. 245-252, 2000.

[07] YALCIN, N.; SEVNIC, V. Utilization of bauxite waste in ceramic glazes. Ceramics International, v. 26, n. 5 , p. 485-493, 2000.

[08] ASOKAN, P.; SAXEAN, M.; ASOLEKAR, S.R. Coal combustion residues-environmental implications and recycling potentials. Resources, Conservation and Recycling, v. 43, n. 3, p. 239-262, 2005.

[09] TSAKIRIDIS, P.E.; AGATZINI-LEONARDOU, S.; OUSTADAKIS, P. Red mud addition in the raw meal for the production of Portland cement clinker. Journal of Hazardous Material, v. 116, n. 1-2, p. 103-110, 2004.

[10] SINGH, M.; UPADHAYAY, S.N.; PRASAD, P.M Preparation of iron rich cement from red mud. Cement and Concrete Research, v. 27, n. 7, p. 1037-1046, 1997.

[11] CABEZA, et al. Red mud as a corrosion inhibitor for reinforced concrete. The Journal of Corrosion Science and Engineering, v. 6, n. 32, p. 1-4, 2003.

[12] GORDON, J.N.; PINNOCK, W.R.; MOORE, M.M. A preliminary investigation of strength development in Jamaican red mud Composites. Cement and Concrete Composites, v. 18, n. 6, p. 371-379, 1996.

[13] SANTOS, L. Avaliação da resistividade elétrica do concreto como parâmetro para a previsão da iniciação da corrosão induzida por cloretos em estruturas de concreto. 161p. Dissertação (Mestrado em estruturas), Departamento de Estruturas, Universidade de Brasília, Brasília, 2006.

[14] BAUER, E. Avaliação comparativa da influência da adição de escória de alto-forno na corrosão das armaduras através de técnicas eletroquímicas. 1995. 236p. Tese (Doutorado), Escola Politécnica, Universidade de São Paulo, São Paulo, 1995

[15] MIRANDA, J.M; et al. Limitations and advantages of electrochemical chloride removal in corroded reinforced concrete structures. Cement and Concrete Research, v. 37, n. 4, p. 596-603, 2007.

[16] SHI, C. Effect of mixing proportions of concrete on its electrical conductivity and the rapid chloride permeability test (ASTM C1202 or ASSHTO T277) results. Cement and Concrete Research, v. 34, n. 3, p. 537-545, 2004.

[17] POLDER, R.B. Test methods for on site measurement of resistivity of concrete - a RILEM TC-154 technical recommendation. Construction and Building Materials, v. 15, n. 2-3, p. 125-131, 2001.

[18] WHITING, D.A.; NAGI, M.A. Electrical Resistivity of Concrete - A Literature Review. Illinois, USA: Portland Cement Association, 2003. 57p. (R\&D Serial No. 2457)

[19] BASHEER, P.A.M.; et al. Monitoring electrical resistance of concretes containing alternative cementitious materials to assess their resistance to chloride penetration. Cement \& Concrete Composites, v. 24, n. 5, p. 437-449, 2002.

[20] MCCARTER, W.J.; STARRS, G.; CHRISP, T.M. Electrical conductivity, diffusion, and permeability of Portland cement-based mortars. Cement and Concrete Research, v. 30, n. 9, p. 1395-1400, 2000.

[21] ANDRADE, C. Calculation of diffusion coefficients in concrete from ionic migration measurements. Cement and Concrete Research, v.23, n. 3, p. 724-742, 1993. 